\title{
LONDON, 1584: TRANSLATION AND CULTURAL POLITICS
}

\section{ALESSANDRA PETRINA ${ }^{1}$}

\begin{abstract}
London, in the year 1584, was a crossroads of cultural exchange, philosophical elaboration, religious dissent. The present contribution focuses on this year considering the circulation of people - especially foreign intellectuals - and books: it looks at the cultural circle established in the household of the French ambassador, Michel de Castelnau; at works such as Giordano Bruno's his Cena de le ceneri and John Florio's First Fruites; at a cultural mediator, William Fowler, and at his translation of Machiavelli's Prince. Through the investigation of the meetings and exchanges that took place in this pivotal year this contribution attempts to shed light on the cultural dynamics, supported by book-buying, translation, quotation and allusion, that constitute such a fundamental element of the construction of Elizabethan culture.
\end{abstract}

KEYWORDS: Giordano Bruno; John Florio; William Fowler; Niccolò Machiavelli; Il Principe.

RESUMO: Londres, no ano de 1584, era uma encruzilhada de intercâmbio cultural, elaboração filosófica e dissidência religiosa. A presente contribuição enfoca este ano, levando em consideração a circulação de pessoas - especialmente de intelectuais estrangeiros - e livros: contempla o círculo cultural estabelecido na residência do embaixador francês, Michel de Castelnau; obras como a A Ceia de Cinzas de Giordano Bruno e First Fruits [Primeiros Frutos] de John Florio; um mediador cultural, William Fowler, e sua tradução do Príncipe de Maquiavel. Através da investigação dos encontros e intercâmbios ocorridos neste ano crucial, a presente contribuição tenta lançar luz sobre a dinâmica cultural, apoiada pela compra de livros, tradução, citação e alusão, que constituem um elemento tão fundamental da construção da cultura elizabetana.

PALAVRAS-CHAVE: Giordano Bruno; John Florio; William Fowler; Niccolò Machiavelli; O Príncipe.

In the second dialogue of his Cena de le ceneri, a philosophical work written in Italian but first published in London, Giordano Bruno famously describes a dinner to which he was invited in 1584, and which took place on the evening of Ash Wednesday, at the house of Sir Fulke Greville. The book, apparently conceived as a tribute to the occasion, mixes philosophical dissertations, mystical suggestions and Bruno's sarcasm against his Oxford colleagues; but here

\footnotetext{
${ }^{1}$ Professora do Departamento de Estudos Linguísticos e Literários (DiSLL) da Università degli Studi di Padova. E-mail: alessandra.petrina@unipd.it.
} 
I would like to focus the reader's attention on the passage describing Bruno and his friends attempting to reach the house of their host (BRUNO, 1999, 363-70). Ash Wednesday is drawing towards sunset, and as Bruno has not received a formal invitation from Greville he believes himself free from that particular engagement, and is away visiting some Italian friends; however, on returning home he finds John Florio, the English writer of Italian descent, and Matthew Gwinne, a Welsh physician and playwright, waiting to accompany him to the dinner, which is going to take place after all. They hurriedly leave, with Bruno praying God "che ne faccia accompagnare in questa sera oscura, a' si lungho camino, per sì poco sicure strade" (BRUNO, 1999, 25). ${ }^{2}$ There is something uncanny about the aptness of Bruno's prayer: in spite of the way being diritta, straight, and relatively easy, they choose to descend to the Thames and make the journey by boat. Here their adventures begin: their ferry-man, resembling Charon in appearance and manners, refuses to take them to their destination and makes them disembark instead near the Temple, from where they walk in the mud, sighing and swearing, until they find themselves back where they had started. Only Bruno's insistence prevents them from giving up: his wish to go to Greville's dinner, he insists, is motivated by his great desire "di ueder costumi, conoscere gl'ingegni, accorgersi si sia possibile di qual che noua uerità, confirmar il buono habito de la cognitione, accorgersi di cosa che gli mancha" (BRUNO, 1999, $32)^{3}$

Whether or not Bruno meant to allude to specific events or accidents of his London sojourn in his description of this episode, the scene is memorable in its evocation of the curiosity of the foreigner, looking for "some new truth", but also of his helplessness in a no-man's-land, symbolically represented by the dark and muddy river Thames. The scene may reflect to some extent Bruno's own life in London. As indicated in the dedication of the Cena, during his English sojourn Bruno found a temporary home not in the Italian community but in the household of the French ambassador, Michel de Castelnau, Seigneur de Mauvissière in Touraine. This was not only one of the centres of political intrigue in London, but also a place where one could meet a number of foreigners, intellectuals and spies. The Anglo-Italian writer and linguist John Florio was employed there as tutor to Catherine Marie, the daughter of the ambassador; while staying at this house Bruno had also the opportunity of meeting Alberico Gentili, the Italian jurist and professor of Roman Law at the University of Oxford. It is well

\footnotetext{
2 "[May God] accompany us in this dark night, on this long journey on such unsafe roads" (translations are mine, unless otherwise indicated).

3 "To see foreign habits, and meet different wits, and grasp the possibility of some new truth, and confirm the good habit of knowledge, and realize what one is missing".
} 
known that some of Mauvissière's employees, including Florio, were also spies for Sir Francis Walsingham (O'CONNOR, 2008, online). At the same time, the French ambassador used his influence also with the Scottish court, attempting to ease the position of Esmé Stuart, cousin to the King of Scotland and former favourite, when Esmé was banned from the Scottish court. French diplomacy was thus proposed as a possible intermediary in the often stormy relations between Scotland and England. Notably, when answering the questions of the inquisitors during his trial in Venice, Bruno would say that the dinner had in fact taken place in the apartments of the French ambassador in Whitehall. Later in the same year, another Italian work Bruno published in London, De la causa, principio et uno, was dedicated to Mauvissière.

The household of Mauvissière, with its intermingling of cultural exchange and political intrigue, may well represent that no-man's-land, political as well as linguistic, in which French, English, Italian and Scottish cultures met and clashed. And if Bruno was one of the most notable guests of the French ambassador, there was another, less known writer whose personality and achievements present many illuminating traits for the scholar who wishes to study Anglo-Italian relations in Elizabethan England. This man was neither English nor Italian: he was a Scotsman, and his name was William Fowler (PETRINA, 2009, 69-86). Born in Edinburgh in 1560, Fowler came of a wealthy burgess family: his father was treasurer of the French revenues for Mary, Queen of Scots, his mother a well-known money-lender. His family had also cultural ambitions: William Fowler's nephew would be William Drummond of Hawthornden, one of the most interesting poetic voices in seventeenth-century Scotland. More importantly, Fowler knew Esmé Stuart: the latter had been the guest of Fowler's mother, both upon his arrival in Scotland in 1582 and when he left the country (LYNCH, 2003, 236). In this article I shall briefly follow Bruno's and Fowler's careers in England in the short period of time indicated by my title, trying to highlight the role of middlemen in philosophical debate.

The scene drawn so far is indicative of one of the most interesting cultural phenomena of Elizabethan England: the cultural exchange that included contributions from different countries and languages, and that was a pivotal element in the transformation of the country from a marginal player on the European chessboard to a nation with a key role. Such cultural exchange found its obvious expression in translation. The scholarly debate on the role of translation in Elizabethan England, a debate that started as early as 1931 with the publication of Otto Matthiessen's Translation. An Elizabethan Art, appears to have highlighted the cultural marginality (and, to a certain extent, isolation) of the country: notable Anglo-Italian translators, such as John Florio, are often mentioned in this debate, and due reference is made to the passage 
in Florio's First Fruites in which one of the characters notes that the English language is "a useful language here in England, but beyond Dover it is worthless" (FLORIO, 1578, 50r). In the third dialogue of Cena de le Ceneri, Giordano Bruno alludes to the same issue. One of his characters, Theophilo, asks Nolano (the writer's alter ego) whether he understands English. The answer is a supercilious negative, since

Non è cosa che lo costringa, o' che l'inclini a' quello, perche coloro che son honorati et gentil huomini co li quali lui suol conuersare; tutti san parlare o' Latino, o' Francese, o' Spagnolo, o' Italiano: i' quali sapendo che la lingua Inglesa non uiene in uso se non dentro quest isola, se stimarebbono saluatici, non sapendo altra lingua che la propria naturale. (BRUNO, 1999, 385) ${ }^{4}$

The passage has been read either as a wry comment on the marginality and insularity of the English language, or as proof of the attitude taken by Bruno when discussing the supposedly provincial English intellectuals with whom he came into contact. Both readings, however, appear to overlook the fact that the English gentlemen Bruno alludes to are said to be conversant either with Latin or with modern vernaculars. Their fear of appearing "wild men" requires them to make a show of linguistic ability. What is also underlined is the desire on the part of these Englishmen to converse in a language other than their own: if, at an individual level, this could be motivated by status anxiety (RHODES, 2011, 108), it is also a useful indication of the desire on the part of English intellectuals to enter an international scene. Between the late Middle Ages and the early modern period, translation became a fundamental factor not only for the development of English literature (from Geoffrey Chaucer, hailed by his contemporaries as a grand translateur, to William Shakespeare, whose masterpieces draw on an extremely wide range of classical and contemporary European sources) but for the evolution of English philosophical and political thought.

The sketch proposed by Bruno, depicting his wanderings on Ash Wednesday, may then be seen as a useful allegory of English intellectual life in the last decades of the twentieth century: although their search was occasionally blind and erratic, English intellectuals did in fact grasp the possibility of some new truth, and confirmed the good habit of knowledge. Religious controversies, especially raging in the south of Europe, opened the possibility for religious dissenters who were escaping Catholic repression to find a welcome in England: London saw some such communities flourishing, and English scholars, translators and printers were quick to avail themselves of this opportunity. In particular, 1584 is an interesting year in that it marks an especially fraught moment in political and cultural encounters in England. The

\footnotetext{
4 "There is nothing that may to force him to learn it, since any honourable gentleman with whom he uses to converse knows either Latin, or French, or Spanish, or Italian; as they know that the English language is not used except within their island, they would believe themselves wild men, if they knew no language but their own".
} 
relations with Italian intellectual life were becoming especially strong, and a number of episodes may be analysed here as supporting this claim.

Giordano Bruno arrived in London in 1583, after escaping first from Catholic Rome, then from Calvinist Geneva. The three years he spent in England were extremely productive, as he wrote no less than six philosophical dialogues during this time. Shortly before arriving in London, he had been at the court of Henry III, in Paris, and thanks to the French king's letters of recommendation had found a welcome at the house of Mauvissière, in London (SACERDOTI, 2019, 192-93). This recommendation might have helped him circumnavigate hostility: we know from a despatch written in March 1583 that the English ambassador in Paris, Henry Cobham, had warned Sir Francis Walsingham, the English Secretary of State and head of Elizabeth's secret service, about the arrival of "a professor of philosophy [...] whose religion I cannot commend" (AQUILECCHIA, 1995, 24). His status as gentilhomo of the French ambassador afforded him a unique point of view: protected by the foreign potentate, he could enter the contemporary philosophical debate in England. Shortly after his arrival, he spent a few days in Oxford (10-13 June 1583), where the University had prepared a series of debates to entertain the Polish Duke Albert Laski. He was invited to one such dispute, and there his views immediately brought him into conflict with John Underhill, then rector of Lincoln College and soon to become vice-chancellor of the University. He was proposing Copernicus against Aristotle, trying to bring the new science within an intellectual environment that was by definition conservative, savagely attacking the Oxonians' devotion to established philosophy. A few years later, remembering the dispute, George Abbot, then doctor of divinity and Dean of the Cathedral in Winchester, would use a contemptuous tone:

When that Italian Didapper, who intituled himselfe, Philotheus Iordanus Brunus Nolanus, magis elaboratae Theologiae Doctor, \&c. with a name longer then his body, had in the traine of Alasco the Polish Duke, seene our Vniversity in the yeare 1583, his hart was on fire, to make himselfe by some worthy exploite, to become famous in that celebrious place. Not long after returning againe, when he had more boldly then wisely, got vp into the highest place of our best $\&$ most renowned schoole, stripping vp his sleeues like some Iugler, and telling vs much of chentrum \& chirculus \& chircumferenchia (after the pronunciation of his Country language) he vndertooke among very many other matters to set on foote the opinion of Copernicus, that the earth did goe round, and the heavens did stand still; wheras in truth it was his owne head which rather did run round, \& his braines did not stand still. (ABBOT, 1604, 88)

Abbot's derogatory tone, and his insistence on Bruno's Italian (involuntarily comic) pronunciation of the key terms of his philosophical proposal, surround the brief mention of the Copernican hypothesis, pre-empting it of any intellectual validity, and, more importantly, 
reducing Bruno's contention to the astronomical proposition, while remaining silent on the philosophical structure that accompanied it. Possibly, Bruno's pitching his wickets in the main university seat in England had not been a good idea: in those years one of the foremost Aristotelians in Oxford, John Case, was publishing his most important works: the same year 1584 saw the publication of Summa veterum interpretum in universam dialecticam Aristotelis, a textbook of Aristotelian logic, in London, while the more important Sphaera civitatis, based on Aristotelian politics, would be published in Oxford in 1588; the following year, both books would be re-published in Frankfurt. Oxford philosophers were keen to reassure the international book market about their unimpeachable orthodoxy.

What we may witness between London and Oxford in those years is the gradual formation of a locus of intellectual and philosophical exchange; if the university, true to its calling, claimed for itself a position as a bastion of conservatism, the openness of contemporary English culture to foreign influences allowed the possibility of debate. John Case, just mentioned here as a representative of philosophical orthodoxy, included among his acquaintances Sir Philip Sidney, the dedicatee of Bruno's Eroici furori and Spaccio de la bestia trionfante, as well as the same Matthew Gwinne, who featured in the Ash Wednesday supper. Sidney, in fact, might have been responsible for taking Case's works to the Frankfurt printer Johann Wechel (LEPRI, 2008, 373), thus ensuring their European circulation.

Interestingly, Bruno's short time in Oxford is also remembered by one N.W., possibly to be identified with Nicholas Whithalk (AQUILECCHIA, 1995, 29), in a letter printed as a preface to Samuel Daniel's English translation of Paolo Giovio's Imprese. The book was published in 1585, and the letter is dated 20 November 1584; in it, N.W. includes a singular little memory of Bruno's Oxford lessons, while encouraging Daniel to feel no shame in presenting to the press a translation from the Italian:

Jouius therefore is bound vnto you, both for absoluting and blazing his inuentions abroad in this famous Iland, and wee are beholding vnto you for reuealing them to vs: wherein truely both arte in translating, \& knowledge in iudging, iustly may chalenge their fees. You cannot forget that which Nolanus (that man of infinite titles among other phantasticall toyes) [t]rruelly noted by chaunce in our Schooles, that by the helpe of translations, al Sciences had their offspring, and in my iudgement it is true. The Hebrewes hatched Knowledge, Greece did nourish it, Italie clothed and beautified it, \& the artes which were left as wards in their minoritie to the people of Rome, by Translators as most carefull Gardiners, are now deduced to perfect age and ripenesse. Concerning the nakednes of your stile (which troubleth you without the colours or florish of Rhetorique) Tullie commendeth it, al Translators approue it: and no man 
maketh so much accompt of the glosse as the substance: of the gay Iuie bush as of the wine. (DANIEL, 1585, iiir-iiiv)

Cultivated and nourished across the centuries and throughout Europe, knowledge finally arrives at its true destination, the "famous Iland" of England: there is a clear political agenda here, since translation allows the nation to develop its cultural identity. The central concept expressed in this passage appears, repeated almost verbatim, in another work, published a few years later: in the preface to his translation of Montaigne's Essais, printed in 1603, John Florio would write:

Shall I apologize translation? Why but some holde (as for their free-hold) that such conversion is the subversion of Universities. God holde with them, and withholde them from impeach or empaire. It were an ill turne, the turning of Bookes should be the overturning of Libraries. Yea but my olde fellow Nolano tolde me, and taught publikely, that from translation all Science had it's ofspring. (MONTAIGNE, 1603, A5r)

Evoking a supposed meeting with Bruno, and turning N.W.'s words into a personal communication, Florio uses this statement for a direct polemics against university teaching, to which, as an aspiring teacher of Italian for the upper classes, he was proposing an alternative. Against the reactionary culture of the universities, Florio proposed a "Science" acquired through linguistic interaction, and fought fiercely against the idea that the dissemination of culture would bring to its debasement: "Why but Learning would not be common. Yea but Learning cannot be too common, and the commoner the better" (MONTAIGNE, 1603, A5r). The intellectual wealth of one community could be augmented through cultural exchange, which could only enrich both source and target cultures. In spite of the controversy accompanying his visit, Bruno had justified those intellectuals that saw in translation one of the roots of the development and extraordinary flourishing of English Renaissance culture.

In a sermon published in 1590, Thomas Rogers, clergyman and religious controversialist, referred to "Anno 84. that fertile year of contentious wrightings" (ROGERS, $1590,2)$. He was alluding to sermons and religious pamphlets published in the endless debate between Anglicans and Puritans; but it is true that writing of all kinds flourished, and that the printing presses were exceptionally busy. Bruno's activity, and the flurry of controversy it generated, are just one instance of a phase in early modern England in which the production of books was only the most visible symptom of a phase of staggering creativity. The activity of translators and printers was criticised, among others, in an anonymous pamphlet called Leicester's Commonwealth, an attack against the Earl of Leicester that has been read as the product of Catholic propaganda, and that was published in the same year, prompting a response 
on the part of Sidney, Defence of the Earl of Leicester, written in the same year: a sign that such activity had important religious and ideological repercussions. The statistics of printing support this point: a search on the Early English Books Online database tells us that almost 300 books were published in England in that year, including the volumes by Giordano Bruno mentioned above. Among the most active printers was John Wolfe, who, among other, less contentious books, would devote himself to contemporary Italian works, publishing a Latin version of Torquato Tasso's Gerusalemme Liberata, some of the most controversial works of Pietro Aretino, and Niccolò Machiavelli's Discorsi and Principe. Bruno's interest in Machiavelli's political works is well known - an interest he shared with another of the guests of the French ambassador, William Fowler.

Fowler's life is an interesting mixture of the courtier, the adventurer and the scholar. After his graduation at the University of St Andrews in 1578, he went to study in Paris, then returned to the British Isles and spent the following years between Edinburgh and London, acting alternatively as a civic officer for the city of Edinburgh, a courtier for young King James VI, a supporter for Esmé Stuart and a spy for Sir Francis Walsingham. The last decade of the sixteenth century saw him travelling across Europe, with powerful patrons such as the Earl of Bothwell, the Laird of Buccleuch, and on the English side, Sir Edward Dymoke and Sir Robert Cecil; in the course of his travels he made the acquaintance of some of the most notable personages of late sixteenth-century Europe, such as the Danish astronomer Tycho Brahe and Jean de Villiers Hotman. In 1592 he enrolled at the University of Padua, and remained there for at least a year; during his Italian period he was probably given a manuscript copy of Philip Sidney's poetic sequence Astrophil and Stella (WOUDHUYSEN, 1996, 358). He may also have met the theologian and historian Paolo Sarpi through a common acquaintance, the Venice printer and bookseller Giovan Battista Ciotti, who used his yearly visits to the Frankfurt book fair to help other Italian friends to communicate with correspondents abroad without fear of the intervening censorship: thus Ciotti was asked by Paolo Sarpi to act as an intermediary in forwarding his letters to Francesco Castrino and others (DE VIVO, 2005, 37-51), and thus he transmitted Giovanni Mocenigo's invitation to Giordano Bruno to come to Venice, where the latter would be denounced and put on trial (BENZONI, 2006, 22). In 1593 Fowler was appointed secretary to Queen Anne of Denmark, King James VI's wife, and in this capacity he followed the royal couple to London after the Union of the Crowns. He lived in London, with occasional trips to Europe, until his death in 1612. 
Fowler's life can thus be read as a significant instance of the early modern humanistaa man who could devote his life to public service thanks to his intellectual abilities, and make a living out of his erudition, intelligence, and linguistic prowess (MANN, 1996, 1-19). The latter characteristic was not only a precious tool in his career as a diplomat, a courtier and a spy, but is the essential instrument of the most significant part of his literary output, which is rich and various - beside a sequence of sonnets that has survived with the title A Tarantula of Love, which shows the influence of Bruno's Eroici furori (ELLIOTT, 2010), and a number of occasional poems, he wrote some polemical prose works and translated Petrarch's Triumphi. Of his various works, the most interesting for our present purpose is another translation, of Machiavelli's Principe, still extant in manuscript, that can be roughly dated to the $1580 \mathrm{~s}$, and which may have used a copy of the Wolfe print as its source text, together with a Latin intermediary translation (PETRINA, 2009, 92-93). The fil rouge uniting intellectuals such as Giordano Bruno and William Fowler goes deeper than the simple sharing of a household. They both drew on one of the most influential and controversial political writers of the sixteenth century, Niccolò Machiavelli. Bruno arguably found in Machiavelli's Prince and Discourses the theoretical basis for his reading of religion as a useful political instrument, a reading appearing in one of the most startling works published in the same fateful year, Spaccio de la bestia trionfante (SACERDOTI, 2019, 197-207), which appeared to draw directly on the Discourses in advocating "religion entirely for pragmatical purposes of a civil and social nature" (AQUILECCHIA, 2002, 10), while Fowler used Machiavelli's masterpiece as a text on which to exercise his considerable linguistic abilities, but also as a work with which he could establish a relation with some of the prominent Scottish noblemen of the time, as shown by the drafted dedication to the Laird of Buccleuch.

There is still much debate concerning the early reception of Machiavelli's book in England and Scotland, and twentieth- and twenty-first-century discoveries of manuscript translations (PETRINA, 2018, 302-333) have done much to dispel the myth that, while Machiavelli himself was for the English little more than the bogus villain appearing on the Elizabethan stage in Marlowe's and Shakespeare's plays, the Principe was only known through Innocent Gentillet's biased, if analytical, reading in what is known as Anti-Machiavel. The Principe itself would only be published in an English translation in 1640, which suggests the paradox of an author discussed, parodied and vituperated long before his most controversial work was actually read. 
Things, of course, are not so simple. Other works by Machiavelli were translated long before Dacres's version of the Principe: the Arte della Guerra had been published in 1560 in a translation by Peter Whitehorne, dedicated to Queen Elizabeth and reflecting the esteem in which Machiavelli's writings on military strategy were held all over Europe (ANGLO, 2005, 32-33); Thomas Bedingfield's version of the Historie Fiorentine appeared in 1595. At the same time, the circulation of Machiavelli's most controversial political works, the Principe and the Discorsi sopra la prima Deca di Tito Livio, was greatly affected, even in contradictory ways, by the insertion of Machiavelli's name in the Roman Index Librorum Prohibitorum, published in 1557 under the papacy of Paul IV. It is evident that, if the Index exercised a strong influence in Italy and other catholic countries such as Spain, it could have a very limited impact in France, and none at all in England or Scotland; on the other hand, the very prohibition to print, sell or own the books enforced by the Papal decree could sort the opposite effect of whetting the perspective readers' curiosity over works that had been banished because of their explicitly sexual references (as was the case with Pietro Aretino) or their inflammatory political content. Printers, sellers and readers then sought alternative means to circulate books whose importance had been effectively boosted by the Index.

The English book market could therefore become important not only for English readers, but also as a source of clandestine copies for the Italian market who could find surreptitious communication channels in the international book fairs, such as the one annually held in Frankfurt, or through the itinerant scholars, intellectuals, dissidents or heretics who fled Italy and sought refuge in England (WYATT, 2005). For all these reasons, the circulation of the Principe in manuscript versions in England long before the publication of Dacres's version in 1640 can be connected to a strong demand on the part of the intellectual community. In fact, it circulated even before the Papal decree, as attested for instance by the presence in the private library of Charlecote Park, in Warwickshire, of a manuscript of the Principe of the first half of the sixteenth century, written in italica hand, probably copied in Italy (WHITFIELD, 1967, 625; WHITFIELD, 1969). Besides, long before the Index the book had been widely read in France, and at least two printed translations, both published in 1553, had enjoyed a wide readership: they were the work of Guillaume Cappel and Gaspard d'Auvergne respectively. Cappel's version, elegant and pithy, was soon imitated by another translator, Jacques Gohory, thus encouraging further circulation throughout the British Isles as well as France. D'Auvergne's work is of particular interest here because it was dedicated to an important Scottish nobleman, James Hamilton, Earl of Arran, Governor of Scotland in 1542 and Duc de 
Châtelheraut in 1548, and therefore constitutes the earliest proof of the transmission of Machiavelli's book to Scotland, or at least to a Scottish milieu. Even more important was the Latin version first published in 1560, shortly after the insertion of Machiavelli's works in the Index: printed in Basel by the Italian immigrant Pietro Perna, it was the work of another refugee, Sylvester Telius, and enjoyed such a widespread readership that by 1699 no less than eighteen editions had been published. The presence of numerous copies of the early editions in Italian as well as English libraries attests not only to the popularity of this translation, but also to its circulation even in countries such as Italy where Machiavelli remained a prohibited author.

It was only a question of time before the potential market value of Italian editions of Machiavelli's works was realised by non-Italian printers, and this is what happened in 1584 in England, thanks to the enterprising John Wolfe. Wolfe had worked in Italy in the 1570s, and once returned to London in 1579 had started working outside the boundaries and obligations of the Stationers' Company (GADD, 2004; HOPPE, 1933, 241-88; SELLERS, 1924, 105-28; HUFFMAN, 1988, 1-43). His probable knowledge of Italian and of the Italian market made him realize the role censorship could play in whetting a potential reader's curiosity for the prohibited, and possibly prompted his printing of Aretino's and Machiavelli's works; he also saw that Italian books could have a double market, in England as well as Italy.

The year 1584 thus brings together the various strands of our research, and gathers the characters and events that have been described so far: it was the year in which Giordano Bruno, then a member of Mauvissière's household, received Fulke Greville's invitation and made the perilous journey through London that would then be immortalised in La cena de le ceneri; it was the year in which William Fowler, surviving Esmé Stuart's disgrace, exile and death, and after working in London as a spy for Francis Walsingham, had become suspicious in the eyes of his former employer, ${ }^{5}$ and was not only planning his return to Scotland but also looking for other patrons, or perhaps employers, in England, such as the Earl of Leicester, and in Scotland, with the Laird of Buccleuch; in Scotland, it was the year in which young James VI, by publishing his poetic manifesto, Reulis and Cautelis, effectively promoted a poetic renaissance that, by explicitly renouncing the Scottish nation's literary heritage, sought its direct inspiration in the national literatures of contemporary Europe, encouraging further translations such as the one Fowler undertook of Petrarch's Triumphi, as noted above. It is, in short, a year in which the

\footnotetext{
${ }^{5}$ As shown in a letter Walsingham wrote to the diplomat William Davison on 13 August 1584, in which he observed: "You do well to deal warily with Fowler. I suspect he is but for an underminer. I do sometimes deliver such baits to my instruments to be delivered unto their entertainers as stolen ware, by corruption of some about me" (READ, 1925, 234).
} 
cultural connections between Italy, England and Scotland, and the link between literature and politics, are strongly highlighted in events taking place between London and Edinburgh, and in the passage of men and books between Italy and the British Isles.

It seems therefore probable that Fowler's encounter with Machiavelli was prompted not so much by his visit to Italy, but by the time he spent in London, moving in a milieu in which Machiavelli's works were discussed and probably read. His acquaintance with Bruno suggests that he knew the Sidneys, in whose circle Machiavelli's works were mentioned with something more than superficial recognition, as is shown by two references Philip Sidney makes to Machiavelli in some of his writings, composed in the fateful year 1584 (PETRINA, 2009, 16); and he might also have heard of the Florentine writer through the Italians living in or in contact with the household of Mauvissière. Since John Wolfe, the enterprising printer, was also in touch with this Italian community and with the Sidneys, it may be surmised that in the early 1580 s some sections of the London intellectual community saw a surge of interest in Machiavelli that involved also a Scottish writer and spy who lived at the intersection of different worlds. There are a number of links between the various member of this variegated group: Alberico Gentili, the Italian jurist and professor at Oxford, who stayed for some time in Mauvissière's house, dedicated his De legationibus libri tres, published in London in 1585, to Philip Sidney; the treatise shows Gentili's acquaintance with Machiavelli's works. ${ }^{6}$ As for Wolfe, he was a friend of Gabriel Harvey and enjoyed the patronage of Philip Sidney. ${ }^{7}$

The encounter between northern European early modern culture and Machiavelli's writings, therefore, passes through English, Scottish and French intermediaries, in a fascinating exchange that marks the truly international character of London in these years. The traditional view of the Elizabethan reception of Machiavelli, linked exclusively to the horrific representations on the Elizabethan stage, must be definitely discarded in favour of a more balanced view that takes into account not only the interest many English (and some Scottish) readers might feel for the political works of the Florentine writer, but also the possibilities offered by the ever-increasing circulation of books, the multiplication of translations, the boost given to cultural exchanges by the more frequent travels from country to country, whether these were determined by business reasons, or by religious necessity. Fowler's translation of the

\footnotetext{
6 The treatise was written in response to the involvement of the Spanish ambassador in the Throckmorton conspiracy (Francis Throckmorton was arrested in 1583). Gentili makes a number of explicit allusions to Machiavelli's works, especially to the Discorsi and the Principe (PANIZZA, 1969, 476-83; ANGLO, 2005, 36769).

${ }^{7}$ In the frontispiece of a book he printed, Giacomo Aconcio's Una essortazione al timor di Dio, Wolfe styles himself "servitore dell'illustrissimo signor Filippo Sidnei” (BASSI, 1997, 452-53).
} 
Principe is by no means the only one of its kind: in the last two decades of the sixteenth century at least four other translations into English appeared, and are still extant in a number of manuscripts. Unfortunately, next to nothing is known of the respective translators, and the various manuscripts in which these texts survive (four manuscripts for the first translation, two for the second, one for the third and one for the fourth) offer very little information. ${ }^{8}$ But, given that the earliest manuscripts are written in recognizably Elizabethan hands, they all point not only to a flourishing intellectual activity around Machiavelli's Principe, but also to a curiosity that prompted these manuscripts to be copied and circulated long before the first printed translation appeared.

As for Fowler, it may therefore be argued that, meeting Machiavelli's text in a context in which it was much cited and discussed, vituperated but also studied, he decided that, as a translator, he would have privileged access to a subject that was exciting such interest and animus. He may also have thought that it was time for the Principe to become better known in Scotland - unlike what happened in England, there are very few and fragmentary traces in sixteenth-century Scotland of the circulation of Machiavelli's works (PETRINA, 2009, 1-45). We do not know whether Fowler's translation ever circulated in his country, or even whether it was ever set in better form than the much corrected and mutilated draft that is all that has survived; in the case of other manuscript translations, we can detect a determined effort on the part of the copyist to make the text not only easy to read but also to consult, as a manual of instructions for the future ruler, while nothing in the Fowler manuscript allows us to draw a similar conclusion. But the context in which this translation can be set points at the same purpose: the exploration of the text, the translator's circumlocutions to analyse and comment Machiavelli's shorter, gnomic but sometimes enigmatic sentences, even Fowler's attempts to use different words to translate the same Italian one, as if to test which one would be more acceptable to the reader; ${ }^{9}$ all these strategies highlight the translator's effort to turn translation into the perfect hermeneutic tool, the ideal help to the circulation of the text in the early modern, babelish world.

\footnotetext{
8 The manuscripts are: for the first translation, London, British Library, Ms Harley 6795.vi, ff. 103r-159v; Cambridge MA, Harvard University, Houghton Library, Ms Eng. 1014; London, British Library, Ms Harley 967; Oxford, Bodleian Library, Ms Ashmole 792.iii, ff. 1r-40r. The second translation is extant in London, British Library, Ms Harley 364.xx, ff. 46r-109v and London, British Library, Ms Harley 2292. The third translation is extant in Oxford, Queen's College Library, Ms 251. Finally, the fourth is extant in London, Lambeth Palace Library, Ms Sion L40.2/E24 (PETRINA, 2009; PETRINA, 2018).

${ }^{9}$ The most obvious instance is Machiavelli's volpe (in the famous passage in which the prince is advised to behave like the lion and the fox, chapter 18), which is translated differently in the same sentence, once as tod and once as fox.
} 
In his essay The Social Function of Poetry, T.S. Eliot writes:

One of the reasons for learning at least one foreign language well is that we acquire a kind of supplementary personality; one of the reasons for not acquiring a new language instead of our own is that most of us do not want to become a different person. (ELIOT, 1957, 19)

Fowler's restlessness, both in his life and in his writings, is revelatory of his continuous search for a social and political identity he could never fully pinpoint. Our exploration of a little segment of early modern no-man's-land, starting with Bruno lost in the foggy Thames, has thus attempted to use one man's intellectual effort to find a guiding thread in the mud of contemporary European thought.

\section{REFERENCES}

ABBOT, G. The Reasons which doctour Hill hath brought, for the vpholding of Papistry, which is falselie termed Catholike Religion. Oxford: Joseph Barnes, 1604.

ANGLO, S. Machiavelli. The First Century. Studies in Enthusiasm, Hostility, and Irrelevance. Oxford: Oxford University Press, 2005.

AQUILECCHIA, G. "Giordano Bruno in Inghilterra (1583-1585). Documenti e testimonianze”. In: Bruniana \& Campanelliana. Pisa, 1, 1995, 21-42.

AQUILECCHIA, G. "Giordano Bruno as Philosopher of the Renaissance". In: GATTI, H. Giordano Bruno. Philosopher of the Renaissance. Farnham: Ashgate, 2002, 1-12.

BASSI, S. "Editoria e filosofia nella seconda metà del '500: Giordano Bruno e i tipografi londinesi". In: Rinascimento. Firenze, 37, 1997, 437-58:

BENZONI, G. “A mo' d'introduzione”. In: PIN, C. Ripensando Paolo Sarpi. Atti del Convegno Internazionale di Studi nel $450^{\circ}$ anniversario della nascita di Paolo Sarpi. Venezia: Ateneo Veneto, 2006, 1-30.

BRUNO, G. La cena de le ceneri. In: CANONE, E. Giordano Bruno. Opere Italiane. Ristampa anastatica delle cinquecentine. Firenze: Olschki, 1999, 363-70.

DANIEL, S. The Worthy tract of Paulus Iouius, contayning a Discourse of rare inuentions, both Militarie and Amorous called Imprese. London: Simon Waterson, 1585.

DE VIVO, F. "Paolo Sarpi and the Uses of Information in Seventeenth-century Venice". In: Media History. 11, 2005, 37-51.

ELIOT, T.S. The Social Function of Poetry (1945). In: On Poetry and Poets. London: Faber, $1957,15-25$.

ELLIOTT, E. “"A memorie nouriched by images': Reforming the Art of Memory in William Fowler's Tarantula of Love". In: The Journal of the Northern Renaissance. 2, 2010, online.

FLORIO, J. Florio His Firste Fruites. London: Thomas Woodcocke, 1578.

GADD. I. "Wolfe, John (b. in or before 1548?, d. 1601)". In: Oxford Dictionary of National Biography. Oxford: Oxford University Press, 2004. 
HOPPE, H.R. "John Wolfe, Printer and Publisher, 1579-1601". In: The Library. London, 14, 1933, 241-88.

HUFFMAN, C.C. Elizabethan Impressions. John Wolfe and his Press. New York: AMS Press, 1988.

LEPRI, V. "Johann Wechel, Giovan Battista Ciotti e le ultime edizioni di Bruno". In: Rinascimento. Firenze, 47, 2008, 367-88.

LYNCH, M. "The Reassertion of Princely Power in Scotland. The Reigns of Mary, Queen of Scots and King James VI". In: GOSMAN, M., MACDONALD, A.A., VANDERJAGT, A. Princes and Princely Culture 1450-1650. Leiden, Boston: Brill, 2003, 199-238.

MANN, N. "The Origins of Humanism". In: KRAYE, J. The Cambridge Companion to Renaissance Humanism. Cambridge: Cambridge University Press, 1996, 1-19.

MATTHIESSEN, F.O. Translation. An Elizabethan Art. Cambridge, Mass.: Harvard University Press, 1931.

MONTAIGNE, M. The Essayes, or Morall and Militarie Discourses of Lo. Michaell de Montaigne ... New Done into English by John Florio. London: Edward Blount, 1603.

O'CONNOR, D. "Florio, John (1553-1625)". In: Oxford Dictionary of National Biography. Oxford: Oxford University Press, 2004; online edn, 2008.

PANIZZA, D. “Machiavelli e Alberico Gentili”. In: Il pensiero politico. Perugia, 2, 1969, 47683.

PETRINA, A. Machiavelli in the British Isles. Two Early Modern Translations of The Prince. Farnham: Ashgate, 2009.

PETRINA, A. “Translating Machiavelli's Prince in Early Modern England: New Manuscript Evidence” In: Manuscript Studies. Philadelphia, 3, 2018, 302-33.

READ, C. Mr Secretary Walsingham and the Policy of Queen Elizabeth. Oxford: Clarendon Press, 1925.

RHODES, N. "Status Anxiety and English Renaissance Translation". In: SMITH, H, WILSON, L. Renaissance Paratexts. Cambridge: Cambridge University Press, 2011, 107-20.

ROGERS, T. A sermon upon the 6.7 and 8. verses of the 12. chapter of S. Paules epistle. London: Iohn Windet, 1590.

SACERDOTI, G. "Giordano Bruno in England: from London to Rome". In: MARRAPODI, M. The Routledge Research Companion to Anglo-Italian Literature and Culture. Abingdon: Routledge, 2019, 192-93.

SELLERS, H. "Italian Books Printed in England before 1640". In: The Library. London, 5, $1924,105-28$.

WHITFIELD, J.H. "The Charlecote Manuscript of Machiavelli's Prince”. In: Italian Studies. Stony Brook, 22, 1967, 6-25.

WHITFIELD, J.H. The Principe, with an Essay on the Prince. Paris: Mouton, 1969.

WOUDHUYSEN, H.R. Sir Philip Sidney and the Circulation of Manuscripts 1558-1640. Oxford: Clarendon Press, 1996. 